\title{
多摩川感潮域の土砂動態に関する研究 MOVEMENT OF FINE SEDIMENT IN THE TAMA RIVER ESTUARY
}

\author{
横山勝英 $^{1} \cdot{\text { 藤田光 }{ }^{2}}^{2}$ \\ Katsuhide YOKOYAMA, Koh-ich FUJTA \\ ${ }^{1}$ 正会員 工博，建設省土木研究所 河川研究室（テ305-0804 茨城県つくば市大字旭一番地） \\ ${ }^{2}$ 正会員 工博 建設省三重工事事務所所長（广514-8502 三重県津市広明町 297）
}

\begin{abstract}
In the Tama River estuary, the behavior of river-bed fluctuation and the movement of bed sediment were investigated by old survey data and field measurement. The results are as follows.

1) The erosion and deposition on river bed were caused regardless of the flood volume, and dredging area was buried in several years. 2) The method for estimating the turbidity from the echo intensity of ADP was developed, and the flux of suspended sediment for a month was calculated. As compared this result with the discharged SS during flood, SS flux of flood was larger than that of tide period. However, the countercurrent during one spring tide eroded and transported 60 (ton) of bed sediment, it is supposed that the transported sediment have large effects on water quality and bed environment.
\end{abstract}

Key Words : tidal current, erosion of river bed, fine sediment, deposition, turbidity and sound intensity

\section{1.はじめに}

沖積河川の河口域は河床勾配がほぼ水平であり, さら に海の潮汐作用によって流れが緩やかになるため, 上流 域では堆積し得ないシルト・粘土などの微細な土砂が堆 積しやすい環境にある. あるいは，微細な土砂が堆積す ることで河口域や沖積平野が形成されてきたとも言える.

このような場所は, 地形, 底質, 潮汐変動などの影響 によって, 汽水性の生物が豊かで漁業活動も盛んである ため重要な自然環境となっている. 一方で, 河口周辺の 低平地には人口が集中するために，河道としての役割は 取水, 航路としての利用, 洪水踈通などが重要である. しかし, 土砂の堆積は河積を減少させるので, 航路維持 や洪水疎通能力の確保のためには浚渫が必要となる場合 もあり, さらに浚渫箇所が再埋没する場合もある.

したがって、河口域の河道を適正に管理するためには, 微細土砂の供給および堆積のメカニズムを明らかにし， 環境管理技術を構築する必要があるといえる.

従来の河口域の研究では, 河川分野では塩水楔運動の 研究, 海岸分野では河口砂州の研究などがそれぞれ詳細 に行われてきているが, 河道および沿岸の土砂動態と地 形変化に関する研究は少ない. 藤田ら ${ }^{1}$ は, 数万年オーダ 一での地形変化に関する検討を行っているが，対象とし ている時間スケールや土砂移動量が地質学的である. ま
た，主に実験室レベルで土砂の堆積・再浮上に関するミ クロな研究が淮められているが 23, , 実際の河川では数年 から数十年単位の堆積機構を精度よく予測することが必 要であり，いずれの研究もこの点においてなお隔たりが あると思われる.

そのため本研究では, 微細土砂の数年程度の時間スケ 一ルでの供給及び堆積の機構をモデル化することを最終 的な目標としている. 本論文ではその基礎的段階として, 多摩川を対象にして過去の測量資料の整理から河床変動 の特徵を調べ, さらに約 1 ケ月間の土砂動態観測を実施 して洪水時と平常時の土砂移動量を比較し, 地形変化へ の影響を考察した. なお, 現地観測においては, 超音波 流速計を用いた新たな土砂観測手法を提案している.

\section{2. 調査対象地の特徵}

\section{(1) 地形}

調査対象地は多摩川の河口域である. 図-1に平面図お よび最深・平均河床縦断図を示す．継断図には後に行う 現地観測の地点も記している. 本研究では微細土砂が堆 積しやすい水域を対象とするため, 河床勾配が概ね水平 になっている河口から $10 \mathrm{~km}$ 付近までを検討区間とした. 図から, 1〜 4km 付近は浅く, 5〜 $7 \mathrm{~km}$ は篞地状の地形と なっていることが分かる. 

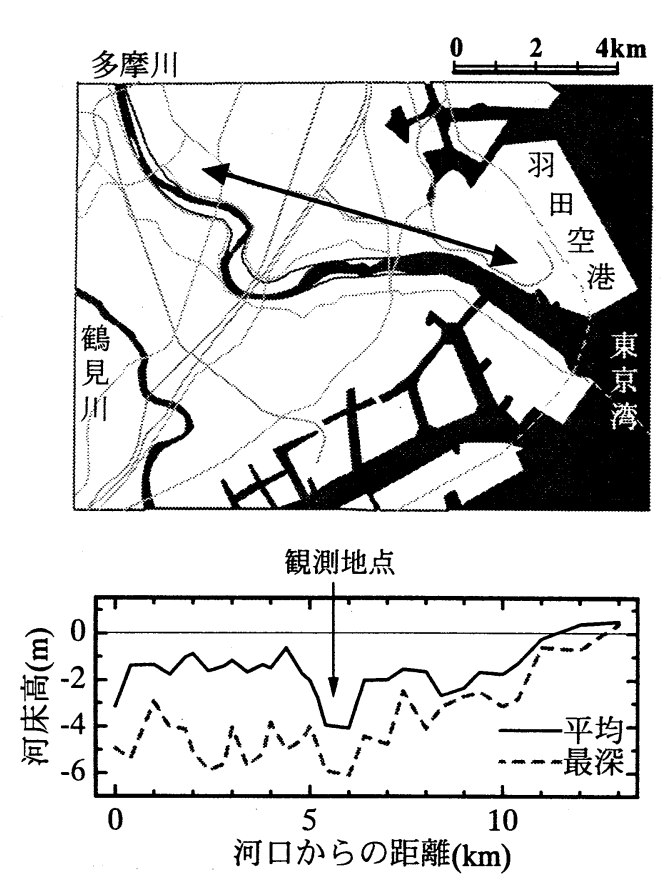

図-1 多摩川感潮域の平面図 (上) と絎断図 (下)

\section{（2）底質}

図-2に 1925 年 ${ }^{4)}$ と 71 年 ${ }^{5}$ の河床材料について, $0 \mathrm{~km}$ 付 近と $4 \mathrm{~km}$ 付近の粒度分布比較図を示す. 1971 年（細線） は地層ボーリングとなっており, 図中の数字は各地層深 度の試験結果を表している. これより，1925 年（大正時 代）には細砂から粗砂であった河床が，約 50 年経過した 後には粘土もしくはシルト質に変化していることが分か る. ただし, 1925 年については, 数值以外の記録として 「水深大となり沈積物中泥土の量多し」「有機物を増す」 とあるため, 場所によってはシルト粘土が堆積していた ものと考えられる. 1971 年については他の調査地点でも シルト質が大半であった. したがって，やはり傾向とし ては河床材料が細粒化したものと考えられる.

この原因としては, 戦後の経済成長に伴う流域排水の 増大が挙げられる. 多摩川の河口域では 1960 年代以降, 有機污泥が厚< (最大 $3 \mathrm{~m}$ 程度) 堆積して水質污濁や悪莫 等が顕著になったため, 環境整備事業として 1971 年(S46) から 1994 年(H6)にかけて浚渫を実施した. 図-3に浚渫位 置を示す. 総浚渫量はおよそ 100 万 $\mathrm{m}^{3}$ であり，また 0 〜 $4 \mathrm{~km}$ で集中的に污泥除去が行われた.

平成に入ってからの変化は，その後の調査資料が得ら れていないので明らかではないが, 現地踏査で $0 \mathrm{~km}$, $2.5 \mathrm{~km}, 5.5 \mathrm{~km}$ の底質を採取したところシルト質であった.

以上より, 河川感潮域には細粒土砂が堆積し易いため に，底質材料は流域変化の影響を強く受けると言える.

\section{（3）河床変動の特徽}

図-4に $1 \mathrm{~km}$ の河床変動履歴と 1968 年を基準とした断 面積の変化時系列，および上流地点の年最大流量時系列 を示す. また, 図-5に $5 \mathrm{~km}$ について同様の図を示す. 図
'25年 $0.5 \mathrm{~km}$ と' 71 年 $0.2 \mathrm{~km}$ の比較

'25年 $4.5 \mathrm{~km}$ と'71年 $4.0 \mathrm{~km}$ の比較

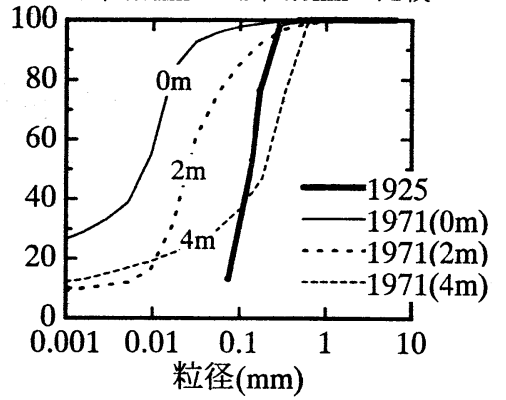

図-2 河床材料の粒度分布図（左:0km 付近，右:4km 付近）

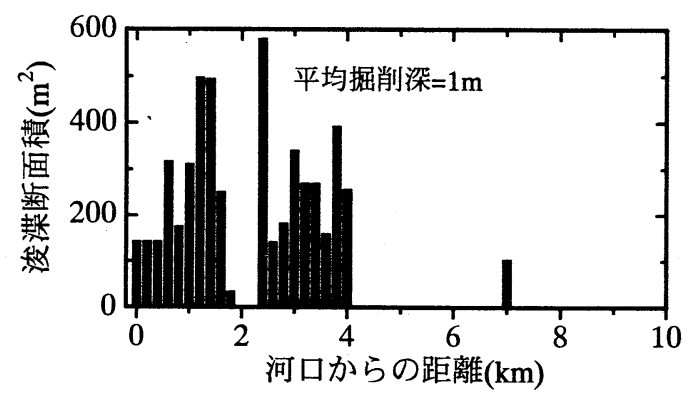

図-3 浚渫実績の綐断分布図

中の番号 (1)〜5) は, 1968 年から 91 年までの測量年を 指したものである. $1 \mathrm{~km}$ は河床地形が浅く有機污泥の浚 渫が実施された場所の例として，5km は窪地状の地形で 浚渫が実施されていない場所の例として示している.

まず, $1 \mathrm{~km}$ (図-4) について見ると, (2)（79 年）に急 激に断面積が増加し, 河床は最大 $2 \mathrm{~m}$ 程度低下しているが, その 2 年後には約 $75 \%$ 程埋め戻り, さらに 2 年後の(3) (83 年）では浚渫により再び河積が増大している. その後は この断面では浚渫が実施されていないため, 徐々に(1)の 河床に復元してゆき, (5) (91 年) ではほぼ元通りになっ ている. (2)の河積増大は, 入手した浚渫記録には記載さ れていないが, 流量記録では 1975 年以降かなり低い流量 が続いていることから, 洪水による洗掘とは考えにくく 人為的な掘削によるものと推測される.

いずれにしても，(2)と(3)の河積増大の直後に 50〜70\% 程度埋め戻っていることが特街的である. 流量との関係 を見ると, 1974 年に過去 30 年間で最大の洪水が生じてい るものの河積はほとんど変わっていないが, (2)と(3)の後 に生じた平均よりも若干大きい洪水によって大部分が埋 まっている. つまり, 河床がある安定した形状から人為 的に変化すると, 元の形状に戻る方向に土砂の移動が生 じ, 戻る速度は数年程度と短い時間であると言える.

図-5に示す $5 \mathrm{~km}$ では, 浚渫は実施されていないが, 横 断形状は(1)から(5)まで堆積と洗掘を繰り返している. 河 積の変化は, (2)と(4)が洗掘, (3)と(5)が堆積であり, 洗掘 から堆積に転じる期間には平均程度の洪水か，もしくは 渴水に近い状態が起きている. とはいうものの, その逆

（渴水だから堆積する）は成立しておらず，流量との明 瞭な相関は見いだせない。

以上の整理を $0 \mathrm{~km}$ から $10 \mathrm{~km}$ までの $200 \mathrm{~m}$ ピッチの 51 


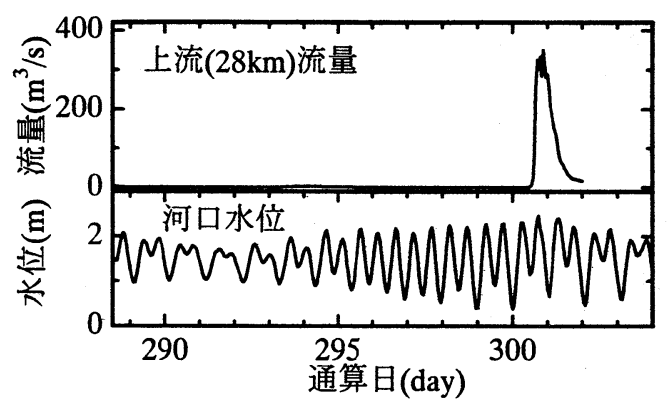

図-7 上流地点 $(28 \mathrm{~km})$ 流量と河口潮位

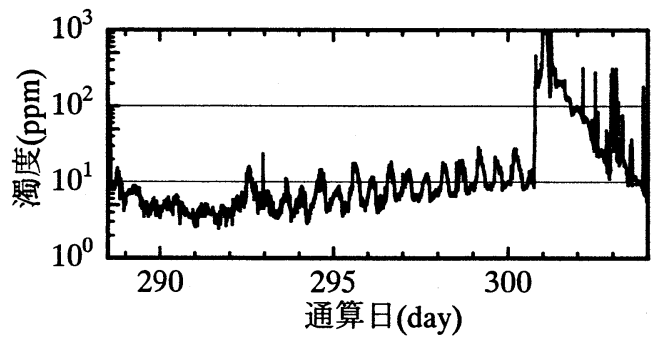

図-8 底層の濁度時系列（河床より $1 \mathrm{~m} ）$ $400\left(\mathrm{~m}^{3} / \mathrm{s}\right)$, 日平均值にすると $180\left(\mathrm{~m}^{3} / \mathrm{s}\right)$ の洪水が発生して いる. 図-4 より，平均年最大日流量は $700\left(\mathrm{~m}^{3} / \mathrm{s}\right)$ であるた め, この出水は中小規模と言える. 河口水位（潮位）は 292 日前後に小潮に, 300 日前後に大潮になっている.

図-8 に底層（河床より $1 \mathrm{~m}$ ) の濁度時系列を示す. 濁度 は小潮時には $5 \mathrm{ppm}$ 程度で安定しているが, 潮位変動が大 きくなるにつれ濁度の上下が活発になり，300 日には 30ppm に達している. これは，潮位変動に伴う順流逆流 運動によって底質が巻き上げられていると推測される.

そこで, これらの様子を更に詳しく見るために，変動 の大きい大潮時 2 日間の濁度と流速の時系列を図-9 に示 す．各図の右軸は流速であり，正の值が順流（上流 $\rightarrow$ 河 口), 負の值が逆流を示している. 大潮時の表層は順流と 逆流が交互に生じて，特に逆流は中層・下層に徐々に伝 搬している．一方，濁度は逆流時に強くなるが，中層で 最も早く上昇し始め，流速との位相も一致している．表 層や底層では流速との対応が悪く位相差も見られる。

以上より，多摩川 $5.5 \mathrm{~km}$ 地点の濁度の上昇は，潮位変 動に伴う逆流が中下層に達する時に顕著に現れる. また, 濁度は中層の流速と良く対応しているので, 下流 1 4km 付近の浅い水路で底泥の巻き上げが生じ，それが $5.5 \mathrm{~km}$ 地点に流れ込んでいると推測される.

\section{4. 土砂動態の計測方法}

感潮域は塩淡混合現象によって流動が複雑なため，土 砂動態を時空間的に把握するためには鉛直濃度分布の計 測が必要となる.しかし、多数の濁度計による計測は労 力と洪水時の危険性を考えると最良ではなく，簡易に濃 度分布を計測する方法が望ましい.

超音波ドップラー流速計は，水中に音波を発射し，浮 遊粒子に当たって反射した際のドップラーシフトを解析
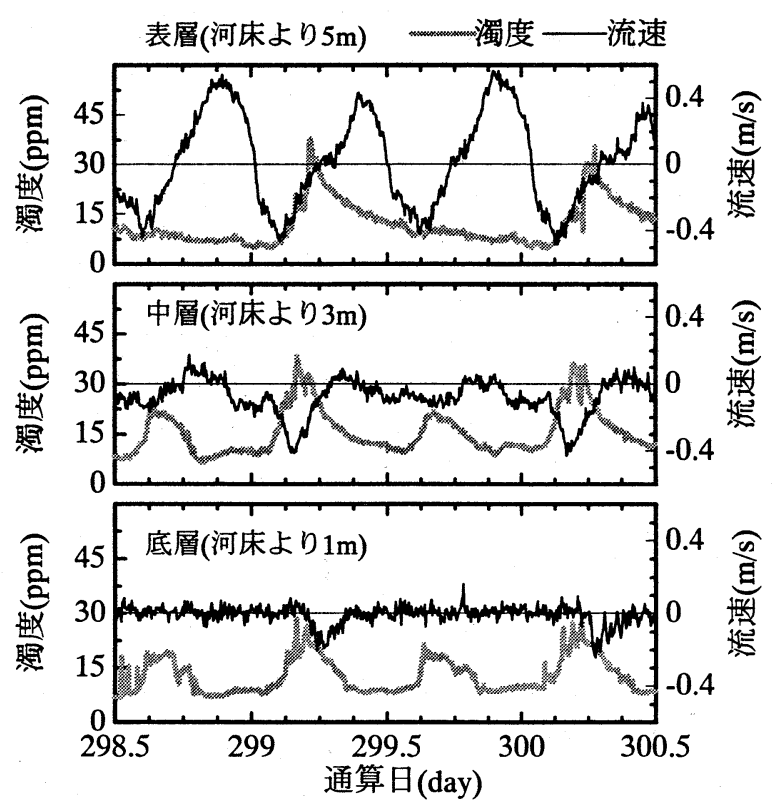

図- 9 大潮時の流速と濁度の関係 (表層・中層・底層)

することにより流速を算出している．そのため，音波の 反射強度自体は水中の粒子濃度と相関が高いと考えられ ており，超音波流速計の副次的な使用方法として検討さ れた例もあるの. ただし，水中超音波の技術は海洋分野で 発展してきたため, 対象とする土砂濃度は河川と比べて 各段に低く，せいぜい十数 ppm が上限であった. 本研究 では河川での土砂観測を目指して，数十 ppm を越える高 濃度場での反射特性について検討を行う。

まず，海洋における音波伝搬理論として，海中を音波 が伝搬する際には諸要因によってエネルギーが損失する 伝搬損失のあることが知られている．伝搬損失は拡散損 失と減衰損失の和として表され，拡散損失は距離の対数 に比例して変化する幾何学的効果, 減衰損失は吸収, 散 乱，その他の影響によるもので距離に比例する効果とし て説明されているわ.これを式で表すと, 次のようになる.

$$
T_{l}=k \log r+2 \alpha r
$$

ここで, $T_{l}$ :伝搬損失 $(\mathrm{dB}), r$ :センサーからの距離, $\alpha$ :吸収 係数である. $\alpha$ は周波数の関数として様々な式が提案さ れているが ${ }^{8)}, f=1.5 \mathrm{MHz}$ の場合, 概ね 0.5 から 0.8 の範囲 にあるため，ここでは $\alpha=0.65 \mathrm{~dB}(\mathrm{~dB} / \mathrm{m})$ とした.

本研究では, 高濁度場での音波の伝搬を計測するため, さらに土粒子による散乱の効果 (減衰損失) を加味する.

$$
T_{l}=k \log r+2 \alpha r+\beta T_{b} r
$$

ここで， $T_{b}$ 濁度， $\beta$ 濁度係数，である.

さて, 現地観測の結果, 濁度と音響強度の対応関係は 図-10のようになった. 図は同一水深における濁度と音響 強度の関係である. なお音響強度の単位は，この計測機 は[count]という単位であり 1count が $0.43 \mathrm{~dB}$ に相当する. 音響強度と濁度の間には相関が見られるが, ばらつきも 1 オーダ一程度認められる．この要因としては，水の物性 

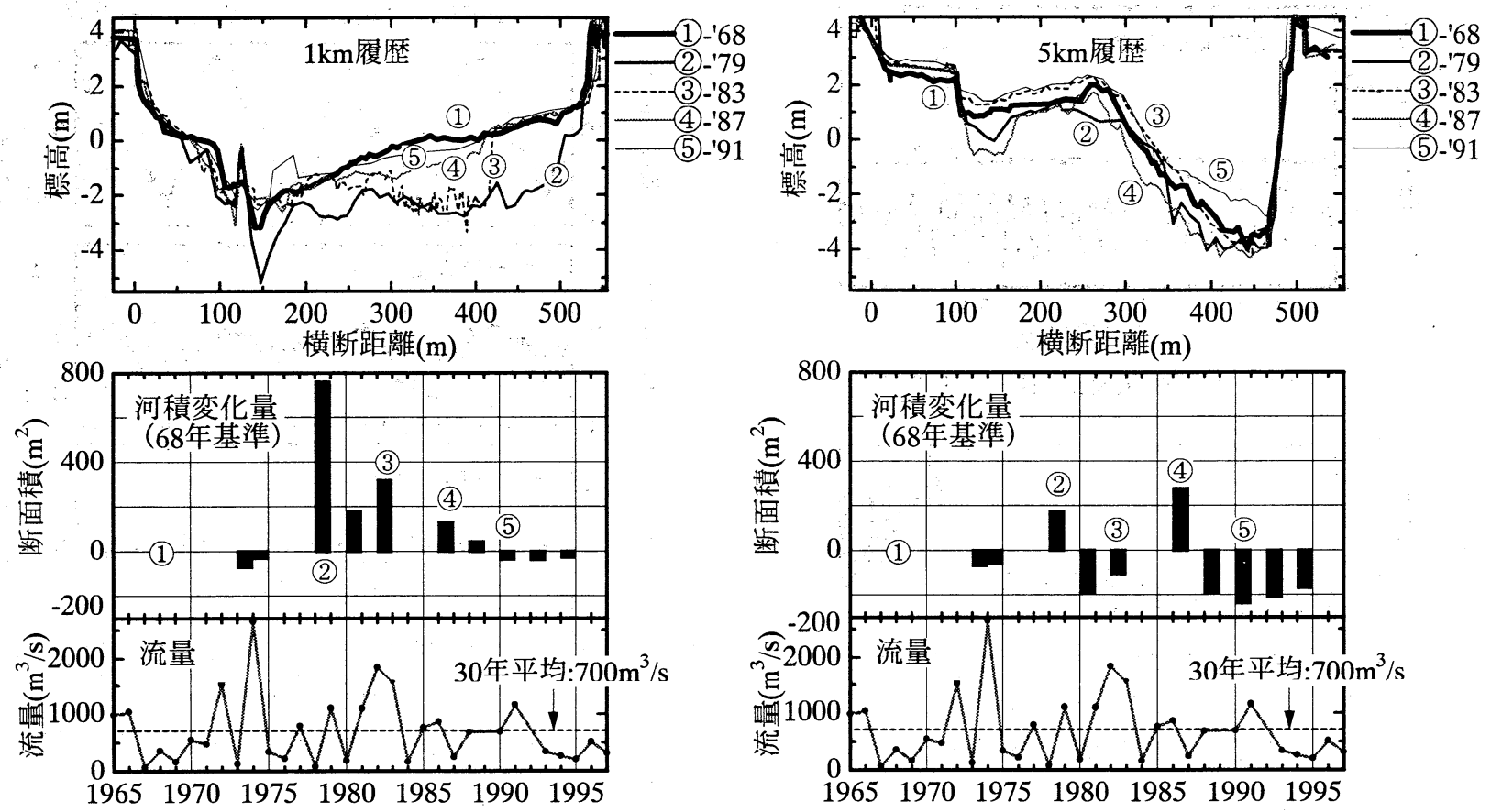

図-4 河床変動履歴，河積変化量と年最大流量（1km)

図-5 河床変動履歷，河積変化量と年最大流量 $(5 \mathrm{~km})$

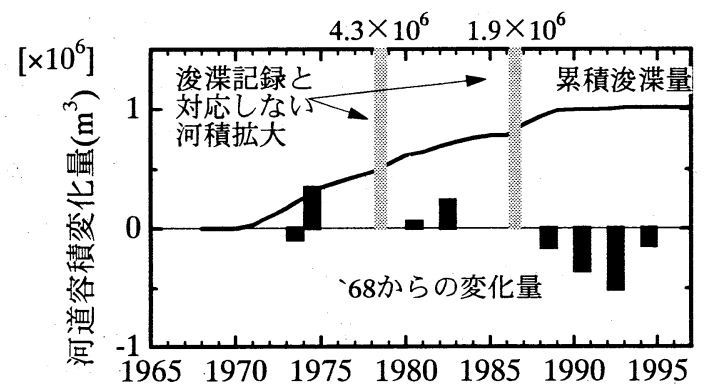

下の洪水しか生じていない期間でも土砂の堆積・流出が 生じている.

そこで次に，この考察がどの程度確からしいのか，そ の可能性を調べるために, 現地で害際に生じている土砂 動態の現地観測を実施した.

\section{3. 現地観測}

図-6 全区間(10km)の容積変化量と浚渫履歴

断面で 11 測量年の全てに対して行い, 河道容積の経年変 化を求めた. その結果を図-6 に示す. また, 浚渫量の累 積時系列も示している. 浚渫量は容積を増大させる行為 なので, 正の值としている.

1968 年からの河道容積の変化量は 1995 年で-15 万 $\mathrm{m}^{3}$ であり,この量は $10 \mathrm{~km}$ 区間全体が $5 \mathrm{~cm}$ 下がったことに 相当するが, 30 年間の変化としてはほぼ元の状態に戻っ たと言える. つまり, 総浚渫量 100 万 $\mathrm{m}^{3}$ は全て埋まった ことになる. 図中のメッシュで印した河積の拡大は, 入 手した浚渫記録と対応していないが, 1979 年に 430 万 $\mathrm{m}^{3}$, 1983年に 190 万 $\mathrm{m}^{3}$ 拡大し, その後に全て埋め戻っている.

1989 年以降は浚渫がほとんど行われていないが, 河道 容積は徐々に減少し, $10 \mathrm{~km}$ 区間全体が $20 \mathrm{~cm}$ 上昇した程 度の堆積が生じている. そして 1995 年には河床低下に転 じている. なお, 図-4 の流量時系列によれば1991 年の洪 水が平均より若干大きいが，それ以外は大した洪水は生 じていない.

以上, 資料整理より得た多摩川感潮域の河床変動の特 徵をまとめると, (1)浚渫等の人為的な河積拡大は, 洪水 規模に係わらず数年程度で埋め戻ってしまう, (2)平均以

\section{（1）観測方法}

観測は $5.5 \mathrm{~km}$ 地点で実施した. 観測地点の縦断位置は 図-1に示したとおりであり, 横断形状は図-5 の $5 \mathrm{~km}$ 地点 とほぼ同じである.この地点は, 川幅が相対的に狭く窪 地状に深い場所である.

現地観測では，断面を通過する土砂量を測定する目的 で流速と濁度の鉛直分布を，また感潮域の基本項目とし て塩分と水温の鉛直分布をそれぞれ計測した．流速は有 線式超音波ドップラー流速計 (NORTEK 社,ADP) を河床 に設置して計測した. センサー周波数は $1.5 \mathrm{MHz}$ ，層厚は $0.4 \mathrm{~m}$ の設定で 5 分間の平均流速を計測した.

濁度, 塩分, 水温の計測にはそれぞれ小型メモリー式 センサー（アレック電子製）を用いた. これらをロープ に結びつけ，アンカーと水中ブイを用いて河床より $1 \mathrm{~m}$, $3 \mathrm{~m}, 5 \mathrm{~m}$ の位置に固定した. 塩分と水温の計測間隔は 10 分, 濁度の計測間隔は 5 分である.

\section{（2）観測結果}

観則期間は 1999 年 10 月 15 日から 11 月 16 日までの約 1 ケ月間である. 図-7 に上流地点 $(28 \mathrm{~km})$ における流量と 河口潮位を示す. 横軸は年間通算日であり 288 日は 10 月 15 日を表している. 流量図によれば 301 日に最大流量 
（水温，塩分，濁度など）が鉛直方向に不均一なこと, 音波の波長（1mm）が浮遊粒子径よりも相当大きいため に散乱応答が悪いこと等が考えられる. 特に, センサー 近傍の音響データもばらついていることから, 後者の影 響が大きいと考えられる. 本研究では, これらの要因に ついて詳細に取り扱うことは困難なため, 均一な場を仮 定した伝搬損失及び高濃度場での散乱について考える.

音響強度と濁度の関係について，前述の伝搬損失を考 慮して式をたてると次のようになる.

$$
40 \log T_{b}=I-B+T_{l}
$$

ここで, $I$ :音響強度, $B$ :基準音圧，である.

(2),(3)式の各係数を求めるには, 最低濁度(1ppm)での音 響強度 $I$ を水深ごとに比較すればよい.ただし, 濁度 $1 \mathrm{ppm}$ は通常の海水状態なので, 土粒子による散乱の項は無視 してよい. これより， $B=80$ (count), $k=65, \alpha=1.5$ (count $/ \mathrm{m}$ ) となり，得られた相関式を図-10に点線で印す。

次に, 高濁度時の土粒子による散乱の項について考え る. 図-10 の高濁度状態（数百 ppm 以上）では音響強度 の増加が抑えられているため, (2)式が実測値に近くなる ように濁度係数 $\beta$ を調整して図中の実線を得た. この時, $\beta=0.004$ であった. 以上を整理すると, 多摩川のこの観 測期間については次式が成立した。

$$
40 \log T_{b}=I-80+65 \log r+3 r+0.004 T_{b} r
$$

図-11 にこの式を用いて音響強度から推定した濁度時 系列と実測濁度の比較を示す. 推定值と実測值は大潮時 の濁度変動時や, 洪水減衰期の高濃度のいずれも比較的 よく合っていることが分かる. さらに大潮時についての 濃度分布図を図-12 に示す. 潮位変動に伴って底層から中 層にかけて高い濁度が発生している様子が詳細に表現さ れており，これらにより超音波流速計による濁度の推定 が実用的であることが示された。

\section{5. 平常時と洪水時の土砂移動量の比較}

\section{（1）観測期間内の移動量}

超音波流速計によって流速と濁度の鉛直分布が同時に 推定できることが示されたので，この両者の值を用いて 単位面積当たりの通過土砂量を計算する. さらに, 河道 横断方向の流速と濁度の分布は一様として, 水深ごとに 通過量と断面積を掛け合わせて断面通過土砂量を計算す る. ここで, 土砂濃度は濁度に等しいと仮定している ${ }^{9}$.

図-13 に断面通過土砂量の順流と逆流成分および合計 を示す．図-7 の河口水位と比較すると，小潮の頃は順流 が卓越し, 潮位変動の増大に伴い逆流成分が大きくなり, 大潮（298～300 日）では逆流が卓越していることが分か る. 同様の計算を洪水終了後の 303 日から 320 日にかけ て行って平常時の移動量を集計し, さらに洪水時の通過
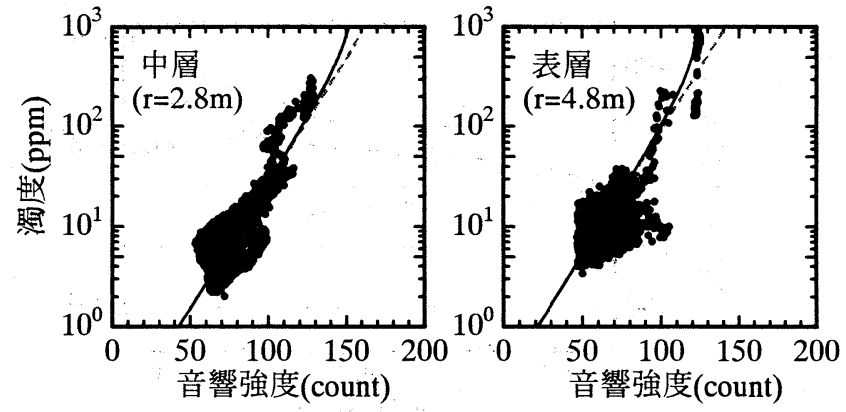

図-10. 音響強度と濁度の対応

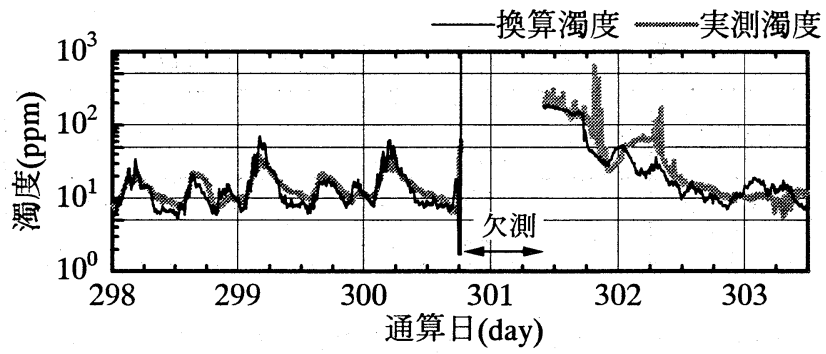

図-11 音響強度より換算した濁度と実測濁度の比較

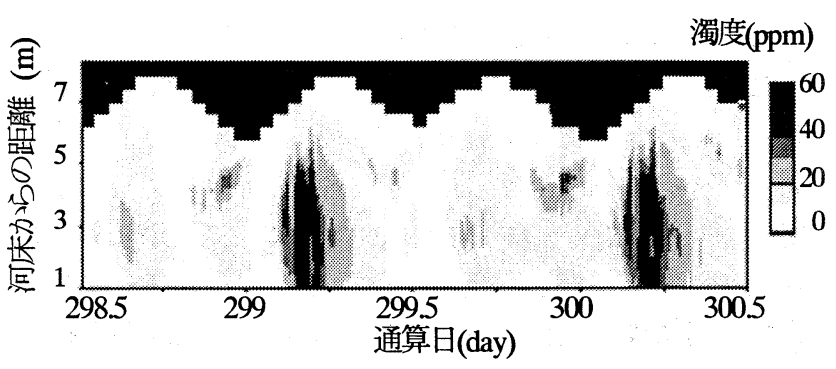

図-12 換算䖲度の鈶直分布時系列

土砂量を濁度と上流の流量から計算すると, 表-1 が求ま った. なお体積は，土砂が緩く溜まった状態を想定して 密度を 1.3 として求めた.

これより, 通過土砂量は平常時よりも洪水時の方がか なり多いことが分かる. あるいは見方を変えて, 潮汐変 動 1 年分と中小洪水 1 回分の移動量が同程度であると考 えれば, 平常時の土砂移動も無視し得ないとも言える. 特に，図-13 に○印で囲った部分では，一回の上け潮（6 時間程度）によって最大 $60($ ton)の土砂が逆流しており, 観測地点の前後で巻き上りや沈降が活発に生じているこ とを示している. こういった平常時の運動は、水質や生 態などに影響を及ぼすと推測される。

\section{（2）流量規模ごとの想定移動量}

洪水時の流量と土砂量の関係を図-14 に示す. 流量と濁 度計測地点は $20 \mathrm{~km}$ 程度離れているため, 洪水伝搬の時間 遅れを考慮して補正している.これにより, 流量一土砂 量の相関式を図中の実線のように求めた. この式を用い て, 先ほどと同様に密度を 1.3 とし, 実測洪水よりも大き な流量規模での供給土砂量を推定すると表 2 のようにな った. ここで, 日平均流量 $630\left(\mathrm{~m}^{3} / \mathrm{s}\right)$ は平均年最大流量, $1,400\left(\mathrm{~m}^{3} / \mathrm{s}\right)$ は 5 年確率程度の流量である. 


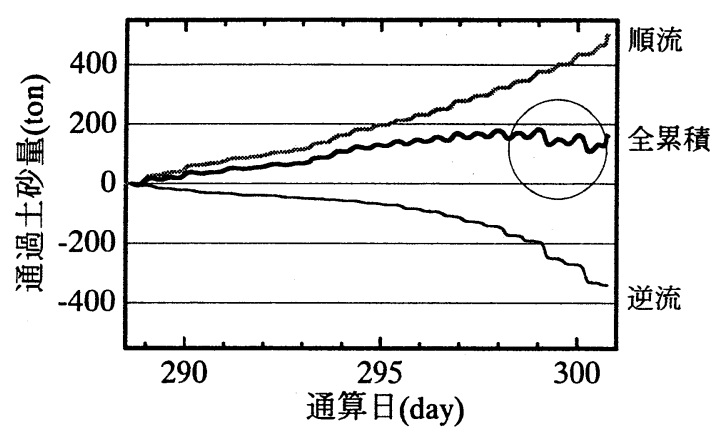

図-13 断面通過土砂量 (累積値)

表-1 平常時と洪水時の通過十砂量の比較

\begin{tabular}{|c|c|c|c|c|}
\hline 移動状態 & 期間 & $\begin{array}{c}\text { 土砂量 } \\
\text { (ton) }\end{array}$ & $\begin{array}{c}\text { 体積 } \\
\left(\mathrm{m}^{3}\right)\end{array}$ & 内訳(ton) \\
\hline 潮汐変動 & 30 日 & 550 & 420 & 順流1,200,逆流650 \\
\hline 洪水 & 2 日 & 6,000 & 4,600 & \\
\hline
\end{tabular}

ただし，この方法で推定する土砂量には数倍から 10 倍 程度の開きがあるから 9 , 大きな流量では表の推定值より も更に大量の土砂が流れている可能性がある.

図-6によれば, 浚渫か行われていない時期 (1990 年代) の変化量は 1 年間に数万から 10 万 $\mathrm{m}^{3}$ 程度, 浚渫記録に 載つている変化量は年平均 5 万 $\mathrm{m}^{3}\left(20\right.$ 年間で 100 万 $\left.\mathrm{m}^{3}\right)$ であり,一方表-2 で平均年最大流量時には 9 万 $\mathrm{m}^{3}$ が供給 されていると推測されたので, その大半が堆積すると仮 定すれば浚渫箇所が短期間に埋没することも説明が付く. ただし，図-6 にメッシュで記した 430 万 $\mathrm{m}^{3}$ と 190 万 $\mathrm{m}^{3}$ の変動量は, 河積拡大後の流量規模が $500 \sim 1,500\left(\mathrm{~m}^{3} / \mathrm{s}\right)$ で あることを考えると，洪水のみでは説明が付きにくい.

\section{6. まとめ}

本研究では, 河川感潮域における微細土砂の供給・堆 積機構を解明するための基礎的段階として, 多摩川の河 口域において資料整理と現地観測により地形変化及び土 砂移動の特徵について検討した結果, 以下の知見を得た.

1)多摩川における過去の環境净化浚渫は, 洪水規模に係わ らず数年程度で埋め戻っていた.

2)平均年最大流量以下の洪水しか生じていない期間でも 土砂の堆積・流出が生じている.

3) $5.5 \mathrm{~km}$ 地点では大潮の逆流時に中層から底層にかけて 高い濁度が観測されたため, 下流の浅い水路で底質が 巻き上っている可能性がある.

4)超音波流速計の音響強度から濁度を推定する式を提案 した.これにより，濁度と流速が同時に計測できる.

5)上記の方法により, 約 1 ヶ月間の土砂移動状況を測定し たところ, 平常時よりも洪水時の土砂移動量が多いこ とが確認された. ただし，大潮の逆流時には一潮汐で 約 60tonの土砂か動いており, 水質や底質に与える影響 が大きいと推測された.

6)実測した流量と土砂量の関係から, 平均年最大流量以上

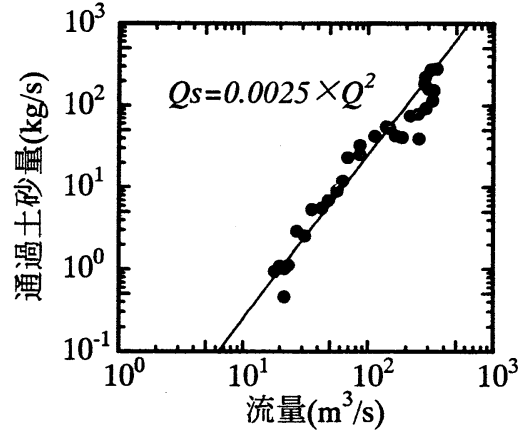

図-14 流量と土砂量の相関

表-2 洪水規模ごとの推定供給土砂量

\begin{tabular}{|c|r|r|r|}
\hline 生起年月 & ピーク流量 & 日平均流量 & \multicolumn{1}{|c|}{ 土量体積 } \\
\hline 1999.9 & $400\left(\mathrm{~m}^{3} / \mathrm{s}\right)$ & $180\left(\mathrm{~m}^{3} / \mathrm{s}\right)$ & $4,600\left(\mathrm{~m}^{3}\right)$ \\
\hline 2000.7 & $1,200\left(\mathrm{~m}^{3} / \mathrm{s}\right)$ & $630\left(\mathrm{~m}^{3} / \mathrm{s}\right)$ & $90,000\left(\mathrm{~m}^{3}\right)$ \\
\hline 1999.8 & $2,300\left(\mathrm{~m}^{3} / \mathrm{s}\right)$ & $1,400\left(\mathrm{~m}^{3} / \mathrm{s}\right)$ & $560,000\left(\mathrm{~m}^{3}\right)$ \\
\hline
\end{tabular}

の洪水での土砂輸送量を推定した. これらの土砂量は その大半が堆積すると仮定すれば, 多摩川での過去の 河積変動履歴を説明しうることが示された. ただし， 過去に 2 回ある大規模な土砂移動については，十分な 説明が為しえず，更に詳細な検討が必要である.

謝辞 : 本研究を行うに際して, 建設省京浜工事事務所に は資料収集及び現地観測の便宜を図って頂いた。 また, 現地観測にあたり土木研究所河川研究室の平館・東氏, ナショナルボートの友光氏，日水コン株式会社の諸氏に は多大なるご協力を頂いた. ここに記して謝意を表する.

\section{参考文献}

1)藤田光一, 山本晃一, 赤堀安宏 : 勾配・河床材料の急変点を持 つ沖積河道繸断形の形成機構之縦断形変化予測,土木学会論文 集 No,660/II-44,pp37-50,1998.

2)近藤雅秋, 平松和昭, 戸原義男, 四ヶ所四男美, 森健 : 底泥表 層部の物性と流れによる巻き上げ特性に関する研究，農業土 木論文集 163,pp79-86,1993.

3)大坪国順, 村岡浩爾 : 底泥の物性およひ限界掃流力に関する実 験的研究，土木学会論文集,No363/II-4,pp.225-234,1985.

4)高田昭 : 多摩川䨾砂利及こ砂に関する調查, 土木試験所報告, 第9号, pp71-92,1927.

5)建設省京浜工事事務所 : 多摩川下流河床土質試験調查書, 1972 6)川西澄，山本洋久，余越正一郎: : 超音波流速計と散乱光式濁 度計を用いた懸濁粒子の濃度,粒径,フラックスの測定, 水工学 論文集,第 42 巻,pp559-564,1998.

7)Robert.J.Urick：水中音響の原理，共立出版株式会社, pp.99-110,1978.

8)実吉淳一, 菊池喜充 能本乙彦: 超音波技術便覧, 日刊工業新 聞社, pp168,1960.

9)横山勝英・梅田信・石川忠晴 : 七ヶ宿貯水池への濁質輸送，第 53 回年次学術講演会概要集,pp750-751,1998.

(2000.10.2 受付) 